\title{
Pengaruh Sistem Informasi SDM, Pelatihan Kerja dan Disiplin Kerja Terhadap Kinerja Karyawan PT Mitra Global Kencana
}

\author{
${ }^{1}$ Riski Eko Ardianto, ${ }^{2}$ Maha Putra \\ Universitas Pelita Bangsa, Bekasi, Indonesia \\ Email : ${ }^{1}$ riskiekoardianto@pelitabangsa.ac.id, ${ }^{2}$ maha.putra@pelitabangsa.ac.id
}

(Diterima: September 2021; Direvisi: Oktober 2021; Dipublikasikan: Januari 2022)

\begin{abstract}
ABSTRAK
Sumber daya manusia merupakan faktor utama dalam menentukan keberhasilan suatu usaha. dalam hal ini karyawan pada PT. Mitra Global Kencana memiliki peran yang sangat penting dalam proses pencapaian perusahaan, oleh karena itu sistem informasi sdm, pelatihan kerja dan disiplin kerja perlu diterapkan untuk tercapainya kinerja karyawan yang baik. Dilihat dari hal tersebut maka rumusan masalah dalam penelitian ini adalah Apakah sistem informasi sdm, Pelatihan kerja dan Disiplin kerja berpengaruh positif dan signifikan terhadap kinerja karyawan? Jenis di dalam penelitian ini adalah penelitian kuantitatif. Pengambilan sampel ini dengan menggunakan teknik sampel jenuh yang mana semua jumlah populasi dijadikan sampel pada penelitian ini yang berjumlah 63 responden, dan pengumpulan data pada penelitian ini meliputi observasi, penyebaran kuesioner dan studi kepustakaan. Teknik analisis data pada penelitian ini yaitu uji validitas, reliabilitas, uji asumsi klasik, analisis deskriptif, analisis linear berganda dan uji hipotesa. dengan menggunakan program aplikasi SPSS Versi 25 yang menunjukan hasil bahwa terdapat pengaruh positif dan signifikan antara sistem informasi sdm, pelatihan kerja dan disiplin kerja terhadap kinerja karyawan secara parsial. Selanjutnya dapat disimpulkan bahwa sistem informasi sdm berpengaruh positif dan signifikan terhadap kinerja karyawan dilihat dari hasil thitung $(6,349)>$ ttabel $(1,998)$ dan nilai signifikansi $(0,000)<(0,05)$, Pelatihan kerja memiliki pengaruh positif terhadap kinerja karyawan dilihat dari thitung $(4,400)>$ ttabel $(1,998)$ dan nilai signifikansi $(0,000)<(0,05)$, dan Disiplin kerja berpengaruh positif terhadap kinerja karyawan dengan hasil thitung $(3,490)>$ ttabel $(1,998)$ dan nilai signifikansi $(0,001)<(0,05)$.
\end{abstract}

\section{Kata Kunci: Sistem Informasi SDM, Pelatihan Kerja, Disiplin Kerja}




\section{PENDAHULUAN}

Dalam era globalisasi saat ini perusahaan dituntut untuk dapat bersaing, saat ini persaingan bisnis menjadi sangat ketat untuk itu perusahaan harus memiliki strategistrategi khusus dalam menjalankan bisnis agar mampu bersaing dan dapat mencapai apa yang menjadi tujuan atas didirikannya perusahaan tersebut. Selain strategi-strategi khusus yang dilakukan, perusahaan juga harus memiliki sumber daya manusia yang mumpuni. Sumber daya manusia adalah suatu aspek yang sangat penting bagi kelangsungan hidup dan perkembangan suatu organisasi, selain itu aktifitas dari suatu organisasi juga memerlukan berbagai sumber daya, salah satunya adalah sumber daya manusia dalam hal ini sumber daya manusia memiliki peranan penting dan sebagai kunci atas keberhasilan perusahaan dalam mencapai tujuan didirikannya organisasi/perusahaan tersebut adanya sumber daya manusia dapat menjadi perencana sekaligus penggerak dalam suatu organisasi sehingga maju mundurnya suatu organisasi akan sangat bergantung pada kualitas sumber daya manusia yang dimiliki.

kesadaran akan hal itu pengelola perusahaan harus dapat menyediakan anggota tenaga kerja yang efektif bagi organisasi sekaligus memberikan perhatian penuh terhadap harapan dan kebutuhan tenaga kerja. Hal ini dikarenakan bahwa sumber daya manusia selain sebagai penggerak tercapainya tujuan organisasi, sumber daya manusai juga merupakan manusia dengan hak dan keinginan yang tidak dapat diabaikan.
Oleh karena itu, berkaitan dengan tuntutan perusahaan untuk selalu berkembang karyawan merupakan suatu faktor dalam organisasi yang perkembangan dan peningkatan kualitasnya harus di persiapkan dengan teliti. Setiap perusahaan tentunya ingin mencapai apa yang menjadi tujuannya, dan hal utama yang dituntut perusahaan dari setiap karyawannya adalah performa karyawan didalam bekerjaini sebagai wadah kumpulan orang-orang yang memiliki kompetensi berbeda-beda namun saling 2 bergantung satu dengan yang lainnya untuk mewujudkan kepentingan bersama. Adapun kinerja karyawan yang diharapkan perusahaan yaitu sesuai dengan standar yang telah ditetapkan.

Dalam artikel Diar Estiwinengku, Zunaidah dan Bambang Bemby Soebyakto yang berjudul The Influence Of Human Resource Training And Work Culture Company Of The Performance Of An Employee Of PT. PP London Sumatra Indonesia (Lonsum) Musi Banyuasin - South Sumatra, dalam International Journal Of Management and Humanities (IJMH) ISSN : 23940913, Volume-3, Issue-12, August 2019. Dijelaskan bahwa pelatihan kerja adalah pembelajaran yang diberikan dalam rangka meningkatkan kinerja dan menambah pengetahuan yang berkaitan dengan pekerjaan saat ini.

Berdasarkan hasil observasi yang dilakukan peneliti pada PT. Mitra Global Kencana, dilihat dari aspek kuantitas yang dihasilkan atas pencapaian target perusahaan bahwa terjadinya penurunan hasil kinerja karyawan yang disebabkan oleh kurang nya penerapan sistem 
informasi sumber daya manusia, kurangnya pengalaman dan pelatihan kerja yang diberikan oleh perusahaan terhadap karyawan serta tingkat kedisiplinan kerja karyawan yang masih sangat kurang.

Didalam proses pencapaian sesuatu yang menjadi kebutuhan dan keinginan, setiap masing-masing individu akan dihadapkan pada halhal baru yang mungkin tidak di duga sebelumnya seperti dalam hal bekerja dengan bekerja individu tersebut akan memperoleh pengalaman dan kemajuan dalam hidupnya. Dalam proses inilah seseorang dapat dilihat kemampuan dan kinerjanya.

Kinerja adalah suatu kondisi yang harus diketahui dan dikonfirmasi kepada pihak tertentu untuk mengetahui tingkat pencapaian hasil suatu instansi dihubungkan dengan visi yang diemban suatu perusahaan serta untuk mengetahui dampak positif dan negatif dari suatu kebijakan operasional (Rismawati dan Mattalata 2018 hal 2). Menurut Hasibuan (2017 : 100) Kinerja adalah hasil kerja yang dicapai setiap pegawai sehingga dapat memberikan kontribusi positif terhadap perusahaan. Kinerja adalah hasil kerja secara kualitas dan kuantitas yang di capai oleh seorang pegawai dalam melaksanakan tugasnya sesuai dengan tanggung jawab yang diberikan kepadanya (A.A Anwar Prabu Mangkunegara, 2015 : 67).

Setiawan (2014:147) dan untuk mengukur kinerja karyawan perusahaan dapat menggunakan indikator-indikator sebagai berikut : 1. Ketepatan Penyelesaian Tugas Merupakan pengelolaan waktu dalam bekerja dan juga ketepatan karyawan dalam menyelesaikan pekerjaan. 2 .
Kesesuaian Jam Kerja Kesediaan karyawan dalam mematuhi peraturan perusahaan yang berkaitan dengan ketepatan waku masuk/pulang kerja dan jumlah kehadiran. 3. Tingkat Kehadiran Jumlah ketidak hadiran karyawan dalam suatu perusahaan selama periode tertentu 4. Kerjasama Antar Karyawan Kemampuan karyawan untuk bekerja sama dengan orang lain dalam menyelesaikan suatu tugas yang ditentukan sehingga mencapai daya guna dan hasil guna yang sebesarbesarnya. 5. Kepuasan Kerja Karyawan Merasa puas dengan jenis pekerjaan yang menjadi tanggung jawabnya dalam perusahaan.

\section{TINJAUAN PUSTAKA}

\section{Sistem Informasi SDM}

Sumber daya manusia dalam suatu organisasi/perusahaan merupakan hal yang esensial untuk menjalankan roda perusahaan dalam mencapai tujuannya. Untuk mencapai tujuannya, perusahaan harus memiliki kinerja karyawan yang optimal, Hal ini tentunya menjadi faktor penting yang perlu diperhatikan oleh perusahaan (Maha Putra April 2021). Sistem informasi sumber daya manusia sebagai suatu sistem yang dapat memberikan informasi untuk pihak-pihak yang membutuhkan secara efektif dan efisien, sehingga informasi yang dihasilkan dapat digunakan dalam pengambilan keputusan dengan tepat. Menurut Raymon McLeod, Jr (2012 : 244), Sistem Informasi Sumber Daya Manusia adalah sistem yang menunjang manajemen untuk mempermudah dalam proses pengambilan keputusan yang meliputi aktivitas merencanakan, 
menerima, menempatkan, melatih dan mengembangkan serta memelihara atau merawat sumber daya manusia atau anggota perusahaan. Dalam lingkungan bisnis global yang dinamis saat ini, perusahaan dituntut untuk dapat menggunakan teknologi informasi untuk menghubungkan banyak orang (Sidh, 2013). Jadi pada pelaksanaannya organisasi bisnis membutuhkan teknologi informasi untuk memperoleh informasi sebagai dasar dalam pegambilan keputusan (Suzanto \& Sidharta, 2015).

Menurut Veithzal Rivai (2009:1015) dalam Jimmy (2016), bahwa indikator sistem informasi sumber daya manusia adalah : 1 . Fungsi Masukan Fungsi masukan berguna untuk memberikan kemampuan untuk memasukan informasi personalia kedalam sistem informasi sdm, meliputi berbagai prosedur yang diperlukan untuk mengumpulkan data. 2. Fungsi Pemeliharaan Data Fungsi pemeliharaan data berguna untuk memproses data yang telah di input sehingga dapat diolah kualitas datanya secara baik dan tersimpan dengan rapih. Fungsi ini memperbaharui, menambah data baru dan mengilangkan data yang sudah tidak diperlukan pada data base. 3. Fungsi Keluaran Fungsi ini memiliki kemampuannya dalam menghasilkan informasi yang diperlukan oleh perusahaan. Hal ini meliputi laporan-laporan standar maupun laporan-laporan khusus. Output/informasi yang disediakan oleh sistem merupakan penghubung penting antara sistem informasi sdm dengan para pengguna sistem tersebut.

\section{Pelatihan Kerja}

Pelatihan merupakan suatu kegiatan yang berguna untuk meningkatkan kemampuan kerja yang dimilikikaryawan, pelatihan dapat menambah pengetahuan secara teoritis dan mampu mengimplementasikannya secara praktis yang bertujuan untuk meningkatkan keterampilan, sikap dan perilaku yang diperlukan dalam usaha mencapai tujuan perusahaan. Yani (2012 : 83) dalam sutiyadi (2013) menyatakan "pelatihan dan pengembangan sumber daya manusia adalah suatu kegiatan untuk meningkatkan kapasitas sumber daya manusia agar bisa menjadi sumber daya yang berkualitas baik dari segi pengetahuan, keterampilan bekerja, tingkat profesionalisme yang tinggi dalam bekerja agar bisa meningkatkan kemampuan untuk mencapai tujuan-tujuan perusahaan dengan baik".

Indikator Pelatihan Kerja

Indikator-indikator pelatihan

menurut Anwar Prabu

Mangkunegara (2012, p.116) diantaranya : 1. Jenis Pelatihan Berdasarkan analisis kebutuhan program pelatihan yang telah dilakukan, maka perlu dilakukan pelatihan peningkatan kinerja karyawan dan etika kerja bagi tingkat bawah dan menengah. 2 . Tujuan Pelatihan Tujuan pelatihan harus konkrit dan dapat diukur oleh karena itu pelatihan yang akan diselenggarakan bertujuan untuk meningkatkan keterampilan kerja agar peserta mampu mencapai kinerja secara maksimal dan meningkatkan pemahaman 
peserta terhadap etika kerja yang harus diterapkan. 3. Materi Pelatihan Materi-materi pelatihan dapat berupa: pengelolaan (manajemen), tatanaskah, psikologis kerja, komunikasi kerja, disiplin dan etika kerja, kepemimpinan kerja dan pelaporan kerja. 4. Metode Yang Digunakan Metode pelatihan yang digunakan adalah metode pelatihan dengan teknik partisipatif yaitu diskusi kelompok, konferensi, simulasi, bermain peran (demonstrasi) dan games, latihan dalam kelas, test, kerja tim dan study visit (studi banding). 5. Kualifikasi Peserta Peserta pelatihan adalah seluruh karyawan yang sudah mendapatkan rekomendasi dari pimpinan. 6. Kualifikasi Pelatih Instruktur yang akan digunakan dalam memberikan materi pelatihan harus memenuhi kualifikasi persyaratan antara lain: mempunyai keahlian yang berhubungan dengan materi pelatihan, mampu membangkitkan motivasi dan mampu menggunakan metode partisipatif. 7. Waktu (Banyaknya Sesi) Banyaknya sesi materi pelatihan terdiri dari 67 sesi materi dan 3 sesi pembukaan dan penutupan pelatihan kerja. Dengan demikian julah sesi pelatihan ada 70 sesi atau setara dengan 52,2 jam. Makin sering petugas mendapat pelatihan maka cenderung kemampuan dan keterampilan karyawan semakin meningkat.

\section{Disiplin Kerja}

Disiplin kerja merupakan alat yang digunakan oleh para manajer untuk berkomunikasi dengan pegawai agar mereka bersedia untuk mengubah suatu perilaku serta sebagai suatu upaya untuk meningkatkan kesadaran dan kesediaan seseorang mentaati semua peraturan perusahaan dan norma-norma sosial yang berlaku. Sedarmayanti $(2011,381)$ mendefinisikan "disiplin adalah melakukan koreksi atau menghukum pegawai yang melanggar ketentuan atau prosedur yang telah ditetapkan orang lain". Sutrisno (2016) mendefinisikan "Disiplin kerja adalah perilaku seseorang sesuai dengan peraturan, prosedur kerja yang ada atau sikap dan tingkah laku serta perbuatan yang sesuai dengan peraturan dari organisasi baik tertulis maupun tidak tertulis". Disiplin merupakan tingkat taat serta kepatuhan pada aturan yang diterima serta bersedia menerima hukuman atau sanksi apabila melewati peraturan yang ditentukan dalam perusahaan (Andry, 2018 : 118).

$$
\text { Menurut Malayu S.P }
$$

Hasibuan (2010:194) dalam Kathleen (2015), indikator disiplin kerja adalah : 1. Mematuhi semua peraturan perusahaan dalam melaksanakan pekerjaannya pegawai diharuskan mentaati semua peraturan perusahaan yang telah ditetapkan sesuai dengan sesuai dengan aturan dan pedoman kerja agar kenyamanan dan kelancaran dalam bekerja dapat terbentuk. 2. Penggunaan waktu secara efektif, waktu bekerja yang diberikan perusahaan diharapkan dapat dimanfaatkan dengan sebaik-baiknya oleh individu untuk mengejar target yang 
diberikan perusahaan kepada individu dengan tidak terlalu banyak membuang waktu yang ada didalam standar pekerjaan perusahaan. 3. Tanggung jawab dalam pekerjaan dan tugas, tanggung jawab yang diberikan kepada individu apabila tidak sesuai dengan jangka waktu yang telah ditetapkan oleh perusahaan maka pegawai telah memiliki tingkat disiplin kerja yang tinggi. 4. Tingkat absensi, salah satu tolak ukur untuk mengetahui tingkat kedisiplinan pegawai, semakin tinggi frekuensi kehadiran atau rendahnya tingkay kemangkiran pegawai tersebut telah memiliki tingkat disiplin kerja yang tinggi. Dari beberapa indikator diatas, tujuan utama perusahaan membuat peraturan yang diberikan kepada individu yaitu untuk mendapatkan tujuan perusahaan yang seideal mungkin agar tujuan perusahaan dapat tercapai.

\section{METODE PENELITIAN}

Penelitian merupakan proses pemecahan suatu masalah dengan melakukan pendekatan dengan metode ilmiah untuk menyelesaikan permasalahan yang ada secara sistematis. Hasil dari penelitian yang dilakukan nantinya adalah teori baru yang berkaitan dengan masalah yang sedang dikaji atau kesimpulan dari dugaan-dugaan yang telah dibuat sebelumnya. Secara garis besar penelitian digolongkan menjadi dua macam yaitu penelitian kualitatif dan penelitian kuantitatif. Jenis penelitian menggunakan pendekatan kuantitatif, jenis ini yang menghasilkan data dalam bentuk angka yang akan disusun berdasarkanpendekatan kuantitatif karena penelitian ini ingin melihat pengaruh hubungan atau pengaruh sebab akibat dari variable. Adapun sumber data yang digunakan pada penelitian ini ada 2 macam yaitu: 1. Data Primer adalah data yang digunakan penelitian iniadalah memberikan selembaran pertanyaanpertanyaan secara langsung kepada karyawan atau yang dikenal dengan data kuesioner. 2. Data Sekunder adalah data yang diperoleh dari literatur-literatur kepustakaan, bukubuku, dan sumber lainnya yang relevan dalam pembahasan dalam penelitian ini.

Desain Penelitian Menurut Silaen (2018 : 23) desain penelitian adalah desain mengenai keseluruhan proses yang diperlukan dalam perencanaan dan pelaksaan penelitian. Penelitian ini terdiri dari empat variabel yaitu SISDM (X1), Pelatihan Kerja (X2), Disiplin Kerja (X3), dan kinerja (Y).

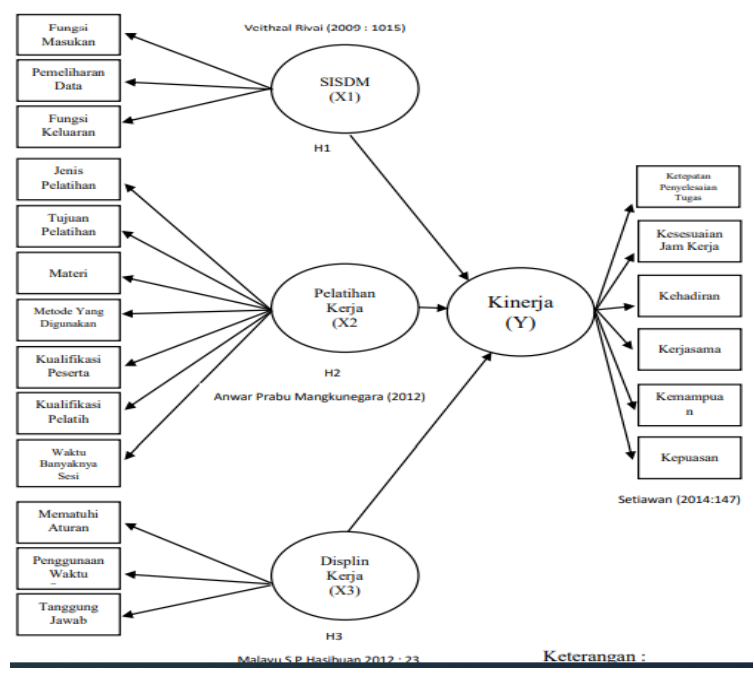

Gambar 1. Metode Penelitian

\section{Teknik Pengumpulan Data}

Teknik pengumpulan data merupakan cara yang dilakukan peneliti untuk mengungkap atau mendapatkan informasi yang dibutuhkan dalam penelitian ini. 
Metode pengumpulan data merupakan salah satu aspek yang berperan dalam kelancaran serta keberhasilan dalam suatu penelitian, karena tujuan utama dari penelitian adalah mendapatkan data (Sugiyono,2019).

Metode pengumpulan data yang digunakan dalam penelitian ini adalah sebagai berikut : 1. Kuesioner, yaitu teknik pengumpulan data dengan cara menyebarkan angket kuesioner yang berisi tentang pertanyaan atau pernyataan yang di berikan kepada 63responden dengan menggunakan skala penilaian responden 1-5, dimana 1 (sangat tidak setuju) sampai dengan skala 5 (sangat setuju). 2. Observasi, yaitu teknik pengumpulan data yang dilakukan dengan cara mengamati secara langsung kondisi PT. Mitra Global Kencana. 3. Wawancara, yaitu teknik pengumpulan data dengan melakukan tanya jawab secara langsung dengan narasumber guna mendapatkan informasi mengenai kestabilan kinerja. 4. Studi Pustaka, yaitu teknik pengumpulan data dengan cara mengumpulkan teori-teori yang relevan, artikel dan literaturlainnya yang berkaitan dengan penelitian ini.

\section{HASIL PENELITIAN \\ Deskripsi Data}

Penelitian ini terdiri dari tiga variable bebas (independen) yaitu sistem informasi sumber daya manusia (X1), pelatihan kerja (X2), disiplin kerja (X3) dan variable terikat (dependen) kinerja karyawan (Y). Penyebaran data yang dilakukan dengan cara mengumpulkan data primer dengan menggunakan instrumen kuesioner dengan memberikan pertanyaan atau pernyataan kepada seluruh populasi yang merupakan karyawan pada PT. Mitra Global Kencana yang berjumlah 63 responden. Dengan metode sampling jenuh maka kuesioner secara keseluruhan sudah diisi dengan lengkap dan diperoleh kembali ke peneliti berjumlah 63 responden.

\section{Analisis Data Atau Pengujian Hipotesis}

Uji validitas digunakan untuk mengukur sah atau valid tidaknya dari masing-masingvariabel tersebut. Uji validitas ini dilakukan dengan cara menghitung korelasi antara skor masingmasing pertanyaan dengan total skor. Pengujian ini menggunakan bantuan Software Statistics Program For Social Science (SPSS) IBM Ver 25.

Dengan membandingkan nilai rhitung dengan nilai rtabel dengan menggunakan tingkat keyakinan $95 \%$, e $=5 \%$ maka dapat dihitung dengan rumus $\mathrm{df}=\mathrm{N}-2$ atau $63-2=61$ (n adalah jumlah sampel), nilai rtabel yang diperoleh sebesar 0,2480 . Uji validitas dapat dikatakan valid dengan kriteria pengujian sebagai berikut : 1 . Jika rhitung >rtable maka item kuesioner tersebut dinyatakan valid. 2. Jika rhitung maka item kuesioner tersebut dinyatakan tidak valid.

Uji Reliabilitas digunakan untuk melihat apakah alat pengukur dapat diandalkan dan tetap konsisten jika di ulang. Uji reliabilitas mengunakan alat uji Cronbach's Alpha $>0,70$ untuk dapat dikatakan reliabel. Berikut adalah tabel rangkuman pengujian reliabilitas masing-masing variabel : 
Tabel 1. Rangkuman Hasil Uji Reliabilitas

\begin{tabular}{|c|l|c|c|c|}
\hline No. & \multicolumn{1}{|c|}{ Variabel } & $\begin{array}{c}\text { N of } \\
\text { Item }\end{array}$ & $\begin{array}{c}\text { Koefisien } \\
\text { Reliabilitas }\end{array}$ & Keterangan \\
\hline 1 & $\begin{array}{l}\text { Sistem Informasi } \\
\text { SDM (X1) }\end{array}$ & 12 & 0,899 & Reliabel \\
\hline 2 & $\begin{array}{l}\text { Pelatihan Kerja } \\
\text { (X2) }\end{array}$ & 26 & 0,844 & Reliabel \\
\hline 3 & $\begin{array}{l}\text { Disiplin Kerja } \\
\text { (X3) }\end{array}$ & 12 & 0,881 & Reliabel \\
\hline 4 & $\begin{array}{l}\text { Kinerja } \\
\text { Karyawan (Y) }\end{array}$ & 24 & 0,954 & Reliabel \\
\hline
\end{tabular}

Berdasarkan tabel di atas dinyatakan bahwa sistem informasi sdm, pelatihan kerja, dan disiplin kerja memiliki Cronbach's Alpha> 0,70, artinya syarat reliabilitas sudah terpenuhi. Dapat disimpulkan bahwa item-item pertanyaan tersebut dapat digunakan sebagai instrument penelitian selanjutnya.

Hasil Uji Asumsi Klasik Perlu dilakukan pengujian asumsi klasik terlebih dahulu atas data yang akan di olah sebelum dilakukanya pengujian analisis regresi linear berganda. Maka perlu dilakukan pengujian terlebih dahulu dengan uji normalitas, multikolonieritas, dan heteroskedastisitas.

Pengujian normalitas dilakukan dengan melihat nilai 2tailed significant. Jika data memiliki tingkat signifikan lebih dari 0,05 atau 5\% maka dapat disimpulkan bahwa Ho diterima atau distribusi data normal. Penelitian ini menggunakan Kolmoogrov-Smirnov Goodness of Fit Test untuk melihat data berdistribusi normal atau tidak. Data ini juga dibandingkan menggunakan Normality Probability Plot.
Tabel 2. Hasil Uji Normalitas

\begin{tabular}{|c|c|c|}
\hline \multicolumn{3}{|c|}{ One-Sample Kolmogorov-Smirnov Test } \\
\hline & & $\begin{array}{c}\text { Unstandardized } \\
\text { Residual }\end{array}$ \\
\hline \multicolumn{2}{|l|}{$\mathrm{N}$} & 63 \\
\hline \multirow[t]{2}{*}{ Normal Parameters ${ }^{\mathrm{a}, \mathrm{b}}$} & Mean & .0000000 \\
\hline & Std. Deviation & 8.35674230 \\
\hline \multirow[t]{3}{*}{ Most Extreme Differences } & Absolute & .092 \\
\hline & Positive & .062 \\
\hline & Negative & -.092 \\
\hline \multicolumn{2}{|l|}{ Test Statistic } & .092 \\
\hline \multicolumn{2}{|l|}{ Asymp. Sig. (2-tailed) } & $.200^{\mathrm{c}, \mathrm{d}}$ \\
\hline \multicolumn{3}{|l|}{ a. Test distribution is Normal. } \\
\hline \multicolumn{3}{|c|}{ b. Calculated from data. } \\
\hline \multicolumn{3}{|c|}{ c. Lilliefors Significance Correction. } \\
\hline \multicolumn{3}{|c|}{ d. This is a lower bound of the true significance. } \\
\hline
\end{tabular}

Berdasarkan tabel di atas menunjukan bahwa hasil pengujian dengan metode KolmoogrovSmirnov Testdengan signifikan 0,200 (Asymp sig (2-tailed) yang > 0,05 dan dapat dikatakan bahwa nilai residual terdistribusi secara normal.

Uji multikolonieritas ini digunakan untuk menguji apakah model regresi ditemukan adanya korelasi antar variabel bebas (independent). Kriteria uji multikolonieritas ini adalah jika nilai Variance Inflation Factor (VIF) $<10$ dan nilai Tolerance $>0,1$ maka dinyatakan bahwa tidak terjadi multikolonieritas antar variabel bebas. Berikut adalah hasil uji multikolonieritas :

Tabel 3. Hasil Uji Multikolinearitas

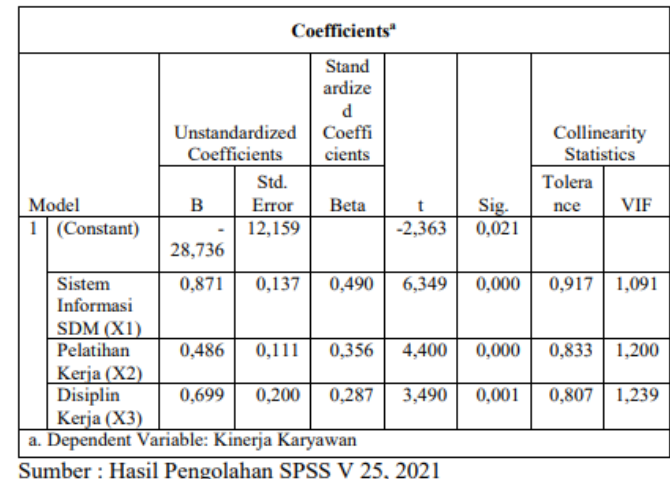

Berdasarkan hasil uji pada tabel

3, dapat diketahui bahwa nilai 
toleransi untuk SISDM (X1) adalah 0,917 , nilai toleransi untuk Pelatihan Kerja (X2) adalah 0,833 dan Disiplin Kerja (X3) adalah 0,807. Hasil yang diperoleh dapat dikatakan bahwa variabel terbebas dari asumsi klasik multikolonieritas karena hasil tolerance $>0,1$. Dan dapat diketahui nilai (Variance Infiation Factor) VIF untuk SISDM (X1) adalah 1.091, Pelatihan Kerja (X2) adalah 1.200, dan untuk Disiplin kerja (X3) adalah 0,239 . Artinya variabel terbebas dari asumsi klasik multikolonieritas, karena nilai VIF $<10$.

Hasil Uji Hipotesis Uji hipotesis bertujuan untuk mengetahui ada atau tidaknya pengaruh yang dinilai signifikan anatara variabel independen terhadap variabel dependen secara parsial dan mengetahui seberapa jauh semua variabel independen berpengaruh erhadap variabel dependen secara simultan. 4.1.6.1 Uji t (Parsial) Uji t ini dilakukan untuk mengetahui apakah dari masingmasing variabel bebas (independen) memiliki pengaruh secara parsial terhadap variabel terikat (dependen). Adapun kriteria uji t ini adalah dengan tingkat signifikansi yang digunakan adalah $5 \%$ atau 0,05, jika Berikut adalah tabel hasil uji $\mathrm{t}$ :

Tabel 4. Hasil Uji t (Parsial)

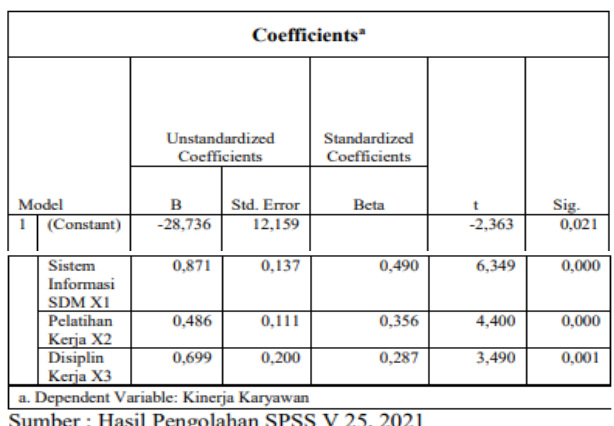

Berdasarkan tabel di atas, dapat dijelaskan sebagai berikut : 1 . Pengaruh sistem informasi sdm terhadap kinerja karyawan (H1) Pada tabel 4.13 dapat dilihat bahwa hasil nilai thitung pada tabel Sistem informasi sdm sebesar 6,349 dan untuk nilai signifikansi sebesar 0,000 , maka dapat diketahui thitung $(6,349)$ $>$ ttabel $(1,998)$ dan nilai signifikansi $(0,000)<(0,05)$, sehingga dapat disimpulkan bahwa Ha diterima dan Ho ditolak. Artinya variabel Sistem informasi sdm (X1) memiliki nilai positif dan berpengaruh terhadap Kinerja karyawan (Y). 2. Pengaruh Pelatihan Kerja terhadap kinerja karyawan (H2) Pada tabel 4 dapat dilihat bahwa hasil nilai thitung pada tabel Pelatihan Kerja sebesar 4,400 dan untuk nilai signifikansi sebesar 0,000, maka dapat diketahui thitung $(4,400)>$ ttabel $(1,998)$ dan nilai signifikansi $(0,000)<(0,05)$, sehingga dapat disimpulkan bahwa Ha diterima dan Ho ditolak. Artinya variabel Pelatihan Kerja (X2) memiliki nilai positif dan berpengaruh terhadap Kinerja karyawan (Y). 3. Pengaruh Disiplin Kerja terhadap kinerja karyawan (H3) Pada tabel 4 dapat dilihat bahwa hasil nilai thitung pada tabel Disiplin Kerja sebesar 3,490 dan untuk nilai signifikansi sebesar 0,001, maka dapat diketahui thitung $(3,490)>$ ttabel $(1,998)$ dan nilai signifikansi $(0,001)$.

Nilai koefisien determinasi (R2 ) berguna untuk memprediksi dan melihat seberapa besar pengaruh yang diberikan variabel $\mathrm{X}$ terhadap variabel Y. Berikut ini hasil analisis uji koefisien determinasi (R2 ) pada penelitian ini dapat dilihat pada tabel dibawah ini : 
Tabel 5. Hasil Uji Koefisien Determinasi $\left(\mathrm{R}^{2}\right)$

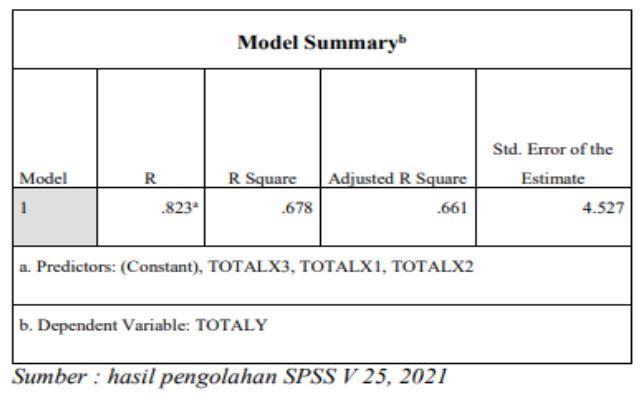

Berdasarkan pada tabel di atas, menunjukan bahwa nilai $\mathrm{R}$ square sebesar 0,678 atau $67,8 \%$ artinya variabel kinerja karyawan dapat dijelaskan sebesar $67,8 \%$ dipengaruhi oleh Sistem informasi sdm, Pelatihan Kerja dan Disiplin Kerja. Selisih (100\% - 67,8\%) sebesar $32,2 \%$ sedangkan sisanya dipengaruhi oleh faktor atau variabel lain yang tidak digunakan dalam penelitian ini.

Uji regresi linear berganda pada penelitian ini menggunakan IBM SPSS Ver.25 pengujian ini untuk mengetahui besarnya pengaruh variabel independent yaitu Sistem Informasi SDM, Pelatihan Kerja, Disiplin Kerja dan untuk variabel dependen yaitu Kinerja Karyawan. Dibawah ini adalah hasil analisis regresi linear berganda pada tabel berikut :

Tabel 6. Hasil Uji Analisis Regresi Linear Berganda

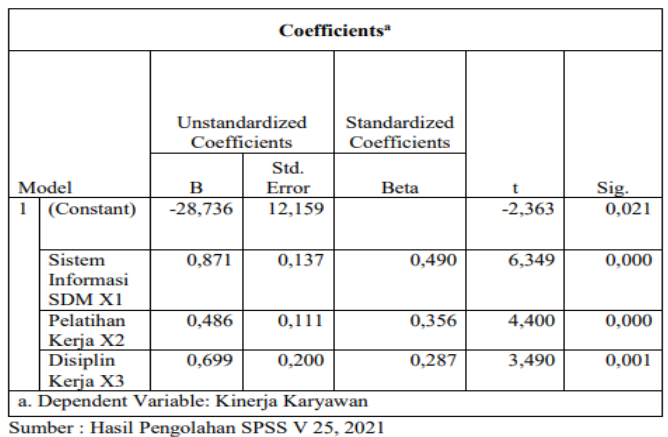

$\mathrm{Y}^{\wedge}=\mathrm{a}^{\mathrm{a}}+\mathrm{b}_{1} \mathrm{X}_{1}+\mathrm{b}_{2} \mathrm{X}_{2}+\mathrm{b}_{3} \mathrm{X}_{3}+\mathrm{b}_{4} \mathrm{X}_{4}+\mathrm{e}$

$Y^{\wedge}=-28,736+0,871 X_{1}+0,486 X_{2}+0,699 X_{4}+0,05$
Berdasarkan tabel di atas hasil analisis regresi linear berganda dapat dijelaskan sebagai berikut: 1 . Konstanta bernilai negatif sebesar $=$ 28,736 Menunjukan bahwa dari setiap variabel independen Sistem Informasi SDM, Pelatihan Kerja dan Disiplin Kerja diasumsikan tidak mengalami perubahan /konstan, maka nilai dari Kinerja Karyawan (Y) akan semakin berkurang. 2. Koefisien dari variable Pelatihan Kerja (X2) sebesar $=0,871$ Dapat di artikan bahwa setiap kenaikan satu skor Pelatihan Kerja dan akan mengalami peningkatan sebesar 0,871 dengan asumsi variabel independen lainya bernilai tetap. 3 . Koefisien dari variabel Disiplin Kerja (X3) sebesar $=0,486$ Menunjukan bahwa setiap kenaikan satu skor Disiplin Kerja akan mengalami peningkatan sebesar 0,486 dengan asumsi variabel independen lainya bernilai tetap.

\section{KESIMPULAN}

Berdasarkan hasil analisis dan pembahasan di atas dilakukannya penelitian ini bertujuan untuk mengetahui pengaruh dari ketiga variabel bebas (independent) yaitu Sistem Informasi SDM (X1), Pelatihan Kerja (X2) dan Disiplin Kerja (X3) terhadap variabel terikat (dependen) yaitu Kinerja Karyawan (Y) hasil dari penelitian ini dapat disimpulkan sebagai berikut: 1. Hasil Hipotesis H1 Variabel sistem informasi $\mathrm{sdm}$ berpengaruh positif dan signifikan terhadap kinerja karyawan yang dibuktikan dengan nilai thitung lebih besar dari tabel yaitu 6,349 diketahui thitung $(6,349)$ $>$ ttabel $(1,998)$ dan nilai signifikansi $(0,000)<(0,05)$, sehingga dapat disimpulkan bahwa Ha diterima dan 
Ho ditolak. Hasil penelitian ini juga memberikan kesimpulan bahwa jika sistem informasi sdm dapat di aplikasikan dengan baik maka akan meningkat pula kinerja karyawan pada perusahaan. 2. Hasil Hipotesis $\mathrm{H} 2$ Variabel pelatihan kerja berpengaruh positif terhadap kinerja karyawan yang dibuktikan dengan nilai thitung lebih besar dari ttabel yaitu 4,400 maka dapat diketahui thitung $(4,400)>$ ttabel $(1,998)$ dan nilai signifikansi $(0,000)<(0,05)$, sehingga dapat disimpulkan bahwa $\mathrm{Ha}$ diterima dan Ho ditolak. Kesimpulan dari hasil penelitian ini jika program pelatihan kerja dilaksanakan dengan baik dan teratur maka produktivitas kerja / kinerja karyawan dapat meningkat. 3. Hasil Hipotesis H3 Variabel disiplin kerja berpengaruh positif dan signifikan terhadap kinerja karyawan yang dibuktikan dengan nilai thitung lebih besar dari ttabel yaitu 3,490 maka dapat diketahui thitung $(3,490)>$ ttabel $(1,998)$ dan nilai signifikansi $(0,001)<(0,05)$, sehingga dapat disimpulkan bahwa Ha diterima dan Ho ditolak. Hal ini berarti indikator yang terdapat dalam disiplin kerja sudah ada dan di aplikasikan sehingga mampu menumbuhkan disiplin kerja dalam diri para karyawan.

\section{DAFTAR PUSTAKA}

A.A Anwar Prabu Mangkunegara. (2015). Manajemen Sumber Daya Perusahaan. Bandung : Remaja Rosdakarya.

Azwar (2014). Metode Penelitian . Yogyakarta : Pustaka Belajar.

Dwi Priyatno. (2016). Belajar Alat Analisis Data Dan Cara Pengolahan nya Melalui SPSS Praktis Dan Mudah Dipahamai
Untuk Tingkat Pemula Dan Menengah. Yogyakarta : Gava Media.

Ghozali. (2014). Aplikasi Analisis Multivariate Dengan Program SPSS. Badan Penerbit UNDIP Semarang.

Hasibuan. (2017). Manajemen Sumber Daya Manusia. Jakarta : Bumi Aksara.

Juliandi, dkk. (2015). Metodologi Penelitian Bisnis.(Medan Umsu Press, 2015)

Juniar. (2013). Faktor Yang Mempengaruhi Keberhasilan Dan Kegagalan Sistem Informasi Manajemen Dalam Penerapannya Disuatu Organisasi.

Malayu S.P (2010). Manajemen Sumber Daya Manusia. Jakarta : Bumi Aksara.

Mangkunegara. (2013). Manajemen Sumber Daya Perusahaan. Remaja, Rosdakarya Bandung.

Nurjaya, N., et al. (2021). Pengaruh Etos Kerja Dan Disiplin Kerja Terhadap Kinerja Pegawai Pada

Dinas Kehutanan Dan

Perkebunan Kota Bogor. JENIUS (Jurnal Ilmiah Manajemen Sumber Daya Manusia), 4(2), 172-184.

Priyatno. (2016). SPSS. Analisis

Data, Olah Data, Dan Penyelesaian Kasus-Kasus Statistik. Yogyakarta : Mediakom.

Putra, Maha, Muhamad Bukhori. (2021). The Influence of Leadership and Work Discipline on The Employees' Performance at PT Tri Centrum Fortuna.

https://ejournal2.pnp.ac.id/inde x.php/jipb. Jurnal IlmiahPoli 
Bisnis, Volume 13No.1 April 2021.

Raymon McLeod, J. (2012). Sistem

Informasi Jilid Dua. Edisi

Bahasa Indonesia. PT. Bhuana

Ilmu Populer, Jakarta 2001.

Rismawati, M. (2018). Evaluasi

Kinerja Penilaian Kinerja Atas

Dasar Prestasi Kerja

Berorientasi Kedepan. Celebes Media Perkasa.

Rivai, Veithzal (2009). Manajemen Sumber Daya Manusia Untuk Perusahaan. Jakarta : Raja Grafindo Persada.

Rudiansyah Noor. (2012).

Metodologi Penelitian . Jakarta

Kencana Prenada Media Group.

Setiawan. (2014). Pengaruh Disiplin

Kerja Dan Motivasi Terhadap
Kinerja Karyawan Pada Rumah Sakit Umum Daerah Kanjuruhan Malang. Jurnal Fakultas Ekonomi Universitas Negeri Surabaya.

Siagian. (2010), Manajemen Sumber Daya Manusia, Jakarta : PT. Bumi Aksara.

Sidh. (2013). Perananan Brainware Pada Sistem Informasi Manajemen. Jurnal Computech \& Bisnis 7 (1), 19-29.

Silaen. (2018), Metodologi Penelitian Sosial Untuk Penulisan Skripsi Dan Tesis. Bogor : In Media.

Sugiyono. (2019). Statistika Untuk Penelitian. Bandung : CV. Alfabeta 